\title{
Cystic intrathoracic derivatives of the foregut and their complications
}

\author{
W. O. KIRWAN, P.R. WALBA UM, and R. J. M. MCCORMACK
}

Edinburgh Cardiothoracic Surgical Unit

It is suggested that these lesions should be classified into three main categories based on embryology-bronchogenic cyst (resulting from a defect of lung budding), intramural oesophageal cyst (true duplication), and enteric cyst (resulting from the split notochord syndrome). A series of 41 patients is reported. Seven of our patients suffered complications, and in two cases these nearly resulted in the death of the patient. These complications are described and their serious import is used to emphasize the desirability of surgical removal of all these foregut derivatives before complications ensue.

Cystic intrathoracic lesions of foregut origin are now well recognized and account for approximately $10 \%$ of lesions presenting as mediastinal tumours (Morrison, 1958). The terminology used to describe mediastinal endodermal cysts has been confused and sometimes ambiguous. The embryological derivation of these lesions has been the cause of much speculation. The purpose of this paper is to report a series of 41 intrathoracic foregut cysts, to show that they fall into three distinct categories on the basis of embryology, to emphasize the occurrence of serious complications, and, for this reason, to urge surgical removal of the lesions.

\section{MATERIAL}

The cases studied were all seen in the period 1948 to 1971 in the Edinburgh Thoracic Unit and are listed in the Table. Fourteen of these cases have already been reported (le Roux, 1962).

\section{EMBRYOLOGY}

The notochord begins to appear in the third week of embryonic life. Occasionally the notochord splits so that a gap is left in the dorsal tissue mass between the two halves of the notochord (Fig. 1). Through this gap the ventrally situated yolk sac or gut anlage may herniate and become adherent to the dorsal ectoderm or skin anlage. This phenomenon, known as the split notochord syndrome (Bentley and Smith, 1960), may give rise to a variety of abnormal endodermal remnants, depending on which part of the dorsal endo- dermal fistula persists. The lesions which may occur are a dorsal enterocutaneous fistula, a dorsal sinus, and a posterior mediastinal cyst. These posterior mediastinal cysts (enteric cysts) are commonly associated with spinal abnormalities.

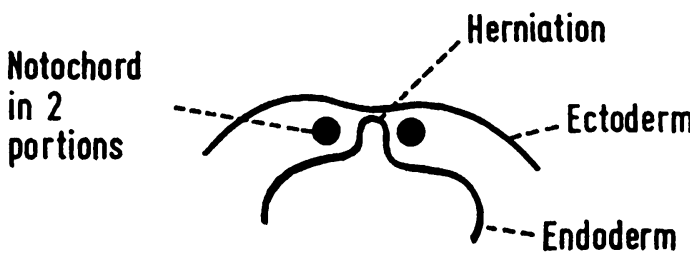

FIG. 1. See text.

The respiratory system develops as a median $\frac{\text { 을 }}{3}$ ventral diverticulum of the foregut. From this diverticulum arises the tracheobronchial tree and $\underset{N}{=}$ the respiratory epithelium of the alveoli. Abnormalos budding of the bronchial tree may give rise to $N$ abnormal cystic structures with or without a N communication with the bronchial tree. These cystic structures are called bronchogenic cysts.

After the fourth week the embryonic oesophagus elongates fairly rapidly. The lining epithelium proliferates, converting the oesophagus into 0 an almost solid tube. At about six weeks vacuoles $\bar{O}^{\circ}$ develop within this solid tube. These vacuoles $\overparen{Q}$ gradually coalesce to form the oesophageal lumen. One vacuole may persist, however, giving rise to음 an intramural oesophageal cyst (a true duplication). 
T A B L E

\begin{tabular}{|c|c|c|c|c|c|c|c|c|}
\hline Case & Age & Sex & Presentation & Site & Lining & $\begin{array}{c}\text { Associated } \\
\text { Abnormalities }\end{array}$ & Complications & Outcome \\
\hline 1 & 34 & $\mathbf{M}$ & Routine $x$-ray & Above left hilum & Ciliated columnar & None & None & Well after \\
\hline 2 & 30 & $\mathbf{M}$ & Chest pain & Right paratracheal & $\begin{array}{l}\text { epithelium } \\
\text { Destroyed by }\end{array}$ & Abnormal & Infection & $\begin{array}{l}\text { resection } \\
\quad,\end{array}$ \\
\hline 3 & 56 & $\mathbf{M}$ & Routine $x$-ray & Behind right hilum & Ciliated columnar & $\begin{array}{l}\text { third right rib } \\
\text { None }\end{array}$ & None & ", \\
\hline 4 & 36 & $\mathbf{M}$ & Chest pain & $\begin{array}{l}\text { Behind right main } \\
\text { bronchus }\end{array}$ & $\begin{array}{l}\text { Ciliated columnar } \\
\text { epithelium }\end{array}$ & None & None & , \\
\hline 5 & 59 & $\mathbf{F}$ & $\begin{array}{l}\text { Repeated respiratory } \\
\text { infections }\end{array}$ & Right hilum & $\begin{array}{l}\text { Ciliated columnar } \\
\text { epithelium }\end{array}$ & None & None & , \\
\hline 6 & 36 & $\mathbf{F}$ & $\begin{array}{l}\text { Opacity seen at } x \text {-ray } \\
10 \text { yr before }\end{array}$ & Left hilum & $\begin{array}{l}\text { Ciliated columnar } \\
\text { epithelium }\end{array}$ & None & None & ", \\
\hline 7 & 23 & $\mathbf{M}$ & Asthma & $\begin{array}{l}\text { Lower end of right } \\
\text { oblique fissure }\end{array}$ & Ciliated columnar & None & None & ", \\
\hline 8 & 19 & $\mathbf{M}$ & $\begin{array}{l}\text { Recurrent respiratory } \\
\text { infections }\end{array}$ & $\begin{array}{l}\text { Right apical lower } \\
\text { segment }\end{array}$ & $\begin{array}{l}\text { Non-ciliated columnar } \\
\text { and squamous } \\
\text { epithelium }\end{array}$ & None & None & , \\
\hline 9 & 21 & $\mathbf{F}$ & Routine $x$-ray & Right paratracheal & Ciliated columnar & None & None & , \\
\hline 10 & 58 & $\mathbf{F}$ & Routine $x$-ray & Below left hilum & Ciliated columnar & None & None & ", \\
\hline 11 & 1 & $\mathbf{F}$ & $\begin{array}{l}\text { Cough, acute febrile } \\
\text { illness }\end{array}$ & Right paratracheal & $\begin{array}{l}\text { Ciliated columnar } \\
\text { epithelium }\end{array}$ & None & $\begin{array}{l}\text { Infection and } \\
\text { stridor }\end{array}$ & , \\
\hline 12 & 24 & $\mathbf{M}$ & Routine $x$-ray & Right hilum & $\begin{array}{l}\text { Ciliated columnar } \\
\text { epithelium }\end{array}$ & None & None & $"$, \\
\hline $\begin{array}{l}13 \\
14\end{array}$ & $\begin{array}{l}20 \\
26\end{array}$ & $\stackrel{\mathbf{F}}{\mathbf{M}}$ & $\begin{array}{l}\text { Routine } x \text {-ray } \\
\text { Chest pain }\end{array}$ & $\begin{array}{l}\text { Right paratracheal } \\
\text { Medial part right } \\
\text { upper lobe }\end{array}$ & $\begin{array}{l}\text { Granulation tissue } \\
\text { Fibrous tissue }\end{array}$ & $\begin{array}{l}\text { None } \\
\text { None }\end{array}$ & $\begin{array}{l}\text { None } \\
\text { None }\end{array}$ & ,", \\
\hline 15 & 56 & $\mathbf{F}$ & $\begin{array}{l}\text { Known to have } \\
\text { cyst } 2 \mathrm{yr}\end{array}$ & $\begin{array}{l}\text { Attached to } \\
\text { posterior wall of } \\
\text { trachea }\end{array}$ & $\begin{array}{l}\text { Ciliated columnar } \\
\text { epithelium }\end{array}$ & None & Stridor & , \\
\hline 16 & 54 & $\mathbf{F}$ & Chest pain & $\begin{array}{l}\text { Left-sided } \\
\text { retrocardiac }\end{array}$ & Fibrous tissue & None & None & $"$ \\
\hline 17 & 63 & $\mathbf{M}$ & Asthma, haemoptysis & $\begin{array}{l}\text { Right pulmonary } \\
\text { ligament }\end{array}$ & $\begin{array}{l}\text { Ciliated columnar } \\
\text { epithelium }\end{array}$ & None & None & " \\
\hline 18 & 24 & $\mathbf{F}$ & Routine $x$-ray & $\begin{array}{l}\text { Attached to } \\
\text { posterior wall of } \\
\text { trachea }\end{array}$ & $\begin{array}{l}\text { Ciliated columnar } \\
\text { epithelium }\end{array}$ & None & None & , \\
\hline 19 & 57 & $\mathbf{F}$ & Cough & $\begin{array}{l}\text { Attached to } \\
\text { posterior wall of } \\
\text { trachea }\end{array}$ & $\begin{array}{l}\text { Ciliated columnar } \\
\text { epithelium }\end{array}$ & None & None & , \\
\hline 20 & 55 & $\mathbf{M}$ & $\begin{array}{l}\text { Haemoptysis, chest } \\
\text { pain }\end{array}$ & Middle lobe & Squamous epithelium & None & Infection & " \\
\hline $\begin{array}{l}21 \\
22\end{array}$ & $\begin{array}{l}50 \\
55\end{array}$ & $\stackrel{\mathbf{M}}{\mathbf{F}}$ & $\begin{array}{l}\text { pain } \\
\text { Routine } x \text {-ray } \\
\text { Routine } x \text {-ray }\end{array}$ & $\begin{array}{l}\text { Right hilum } \\
\text { Right hilum }\end{array}$ & $\begin{array}{l}\text { Squamous epithelium } \\
\text { Ciliated columnar } \\
\text { epithelium }\end{array}$ & $\begin{array}{l}\text { None } \\
\text { None }\end{array}$ & $\begin{array}{l}\text { None } \\
\text { None }\end{array}$ & ", \\
\hline 23 & 65 & $\mathbf{M}$ & Routine $x$-ray & Right hilum & $\begin{array}{l}\text { Ciliated columnar } \\
\text { epithelium }\end{array}$ & None & None & , \\
\hline 24 & 47 & $\mathbf{F}$ & Routine $x$-ray & Right hilum & $\begin{array}{l}\text { Ciliated columnar } \\
\text { epithelium }\end{array}$ & None & None & , \\
\hline 25 & 36 & $\mathbf{M}$ & $\begin{array}{l}\text { Chest pain, collapse, } \\
\text { venous engorgement }\end{array}$ & $\begin{array}{l}\text { Right posterior } \\
\text { mediastinum }\end{array}$ & $\begin{array}{l}\text { Non-ciliated columnar } \\
\text { epithelium }\end{array}$ & None & $\begin{array}{l}\text { Infection, } \\
\text { cardiac } \\
\text { tamponade }\end{array}$ & ", \\
\hline 26 & 29 & $\mathbf{M}$ & Routine $x$-ray & Right paratracheal & $\begin{array}{l}\text { Ciliated columnar } \\
\text { epithelium }\end{array}$ & None & None & $"$ \\
\hline 27 & 16 & $\mathbf{F}$ & $\begin{array}{l}\text { Repeated respiratory } \\
\text { infections }\end{array}$ & $\begin{array}{l}\text { In oesophageal } \\
\text { wall }\end{array}$ & $\begin{array}{l}\text { epithelium } \\
\text { Non-ciliated columnar } \\
\text { epithelium }\end{array}$ & None & None & , \\
\hline 28 & 22 & $\mathbf{M}$ & Routine $x$-ray & $\begin{array}{l}\text { In lower } \\
\text { oesophageal wall }\end{array}$ & $\begin{array}{l}\text { Ciliated columnar } \\
\text { epithelium }\end{array}$ & None & None & , \\
\hline 29 & 15 & $\mathbf{F}$ & Routine $x$-ray & $\begin{array}{l}\text { In lower } \\
\text { oesophageal wall }\end{array}$ & $\begin{array}{l}\text { Stratified squamous } \\
\text { epithelium }\end{array}$ & None & None & , \\
\hline 30 & 65 & $\mathbf{M}$ & $\begin{array}{l}\text { Found at operation } \\
\text { for hiatus hernia }\end{array}$ & $\begin{array}{l}\text { In herniated part } \\
\text { of stomach wall }\end{array}$ & Gastric mucosa & Hiatus hernia & None & ", \\
\hline 31 & 40 & $\mathbf{M}$ & Routine $x$-ray & $\begin{array}{l}\text { In lower } \\
\text { oesophageal wall }\end{array}$ & $\begin{array}{l}\text { Ciliated columnar } \\
\text { epithelium }\end{array}$ & None & None & $\begin{array}{l}\text { Died of } \\
\text { oesophageal } \\
\text { perforation } \\
36 \text { hrostop. }\end{array}$ \\
\hline 32 & 29 & $\mathbf{M}$ & Chest pain & $\begin{array}{l}\text { In lower } \\
\text { oesophageal wall }\end{array}$ & $\begin{array}{l}\text { Ciliated columnar } \\
\text { epithelium }\end{array}$ & None & None & $\begin{array}{l}\text { Well after } \\
\text { resection }\end{array}$ \\
\hline 33 & 27 & $\mathbf{M}$ & Dysphagia & $\begin{array}{l}\text { In lower } \\
\text { oesophageal wall }\end{array}$ & $\begin{array}{l}\text { Ciliated columnar } \\
\text { epithelium }\end{array}$ & Hiatus hernia & None & ", \\
\hline 34 & 21 & $\mathbf{F}$ & Lassitude & $\begin{array}{l}\text { In lower } \\
\text { oesophageal wall }\end{array}$ & $\begin{array}{l}\text { Ciliated columnar } \\
\text { epithelium }\end{array}$ & None & None & $"$ \\
\hline 35 & 65 & $\mathbf{M}$ & $\begin{array}{l}\text { Weight loss; } \\
\text { pyrexia; coughing } \\
\text { up foul material }\end{array}$ & $\begin{array}{l}\text { Posterior } \\
\text { mediastinum }\end{array}$ & Granulation tissue & None & Infection & $"$ \\
\hline 36 & 36 & $\mathbf{F}$ & Routine $x$-ray & $\begin{array}{l}\text { Right inferior } \\
\text { posterior } \\
\text { mediastinum }\end{array}$ & $?$ & None & None & $\begin{array}{l}\text { Declined surgery, } \\
\text { Well } 6 \text { yr later }\end{array}$ \\
\hline 37 & 24 & $\mathbf{M}$ & Routine $x$-ray & $\begin{array}{l}\text { Tubular right } \\
\text { posterior } \\
\text { mediastinal cyst } \\
\text { attached to } \mathrm{T} 3\end{array}$ & $\begin{array}{l}\text { Mixed squamous and } \\
\text { ciliated epithelium }\end{array}$ & $\begin{array}{l}\text { Sharp ridge } \\
\text { down front of } \\
\text { thoracic spine } \\
\text { with con- } \\
\text { genital defect } \\
\text { of lower } \\
\text { cervical spine } \\
\text { None }\end{array}$ & None & $\begin{array}{l}\text { Well after } \\
\text { resection }\end{array}$ \\
\hline
\end{tabular}


T A B LE (contd.)

\begin{tabular}{|c|c|c|c|c|c|c|c|c|}
\hline Case & Age & Sex & Presentation & Site & Lining & $\begin{array}{c}\text { Associated } \\
\text { Abnormalities }\end{array}$ & Complications & Outcome \\
\hline 39 & 32 & $\mathbf{F}$ & Dyspnoea & $\begin{array}{l}\text { Upper posterior } \\
\text { mediastinum } \\
\text { adherent to spine } \\
\text { Anterior to D6 }\end{array}$ & Granulation tissue & $\begin{array}{l}\text { Upper dorsal } \\
\text { scoliosis, } \\
\text { wedging of D4 } \\
\text { Wedging of }\end{array}$ & $\begin{array}{l}\text { None } \\
\text { None }\end{array}$ & , \\
\hline 41 & 17 & $\mathbf{F}$ & $\begin{array}{l}\text { mitral valvotomy } \\
\text { Epigastric pain; } \\
\text { haematemesis; } \\
\text { haemoptysis }\end{array}$ & Anterior to D6 & $\begin{array}{l}\text { epithelium } \\
\text { Gastric mucosa }\end{array}$ & $\begin{array}{l}\text { of D6 } \\
\text { Anterior } \\
\text { wedging of D6 }\end{array}$ & $\begin{array}{l}\text { Peptic } \\
\text { ulceration, } \\
\text { bronchiectasis }\end{array}$ & , \\
\hline
\end{tabular}

\section{TERMINOLOGY AND DEFINITION}

The term 'cystic foregut derivative' includes a group of different lesions which have been called bronchogenic cysts, tracheobronchial cysts, oesophageal cysts, gastric cysts, enterogenous cysts, and duplications. Confusion has arisen because different authors have used different reasons for their classifications: thus some classifications are based on anatomical site, some on embryology, and some on epithelial lining. After examination of our cases we believe the most sensible classification of cystic foregut derivatives is one based on embryological origin and anatomical location rather than on epithelial lining. The classification used in this paper is similar to that used by Fallon, Gordon, and Lendrum (1954), and we believe that three main categories of foregut derivatives are found in the thorax: bronchogenic cyst ; intramural oesophageal cyst; and enteric cyst.

BRONCHOGENIC CYST Our cases 1 to 26 fall into this group. These lesions are closely related to the bronchial tree, are usually lined with ciliated columnar epithelium, and often have cartilage in their walls. They are considered to result from abnormal budding of the bronchial tree (Laipply, 1945; Maier, 1948). It is probable that part of the lung bud becomes nipped off and develops separately to produce a bronchogenic cyst. Bronchogenic cysts are never associated with vertebral abnormalities and are distinct lesions from the ciliated intramural oesophageal cyst described below.

INTRAMURAL OESOPHAGEAL CYST Cases 27 to 34 fall into this group. These lesions lie in or close to the oesophageal wall and are usually lined by ciliated columnar epithelium, although cases 27 and 29 had non-ciliated columnar and squamous epithelium respectively. The likely embryological explanation of these lesions is that they represent true duplications, the result of defects in the vacuolation process as above described. Fallon $\stackrel{\infty}{\infty}^{-}$ et al. (1954) suggested the name intramural oesophageal cyst for these lesions. These cysts are never associated with vertebral abnormalities.

ENTERIC CYST Cases 35 to 41 fall into this group. These are cystic structures lying in the posterior mediastinum and usually separate from the oesophagus. They have a variable epithelium and a muscular wall resembling that of the intestine. Their attachment is posteriorly to the spine (Fallon et al., 1954; le Roux, 1962). They are commonly associated with vertebral abnormalities, as in cases 37, 39, 40, and 41. Embryologically these lesions are part of the split notochord syndrome already described. These cysts are usually firmly attached to the body of the vertebra by fibrous tissue which results from degeneration of that part of the fistula which penetrates the spine.

Because the spine and foregut elongate at a different rate the final position of the cyst is ఖ caudal to that of the vertebral defect. Radio- $\frac{\sigma}{0}$ graphs of the cervical and upper dorsal spine may 3 therefore be necessary to demonstrate these vertebral defects.

\section{PRESENTATION}

The majority of our cases were asymptomatic anó were diagnosed on routine radiography or by an incidental film during the investigation of $O$ another condition. Four were discovered as sur- $N$ prise findings at thoracotomy performed for ano- N ther condition (cases 30,33, 40, and 41). Three patients had asthma, but we believe this to be an incidental association. Seven of our patients $\frac{C}{\mathbb{C}}$ presented with some complication.

\section{COMPLICATIONS}

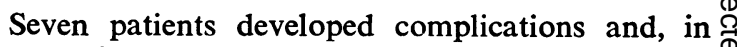
two of these (cases 25 and 35), the resulting ill- $\stackrel{\mathcal{Q}}{\Omega}$ ness was grave.

INFECTION This was the most common complica- 
tion and occurred in five cases $(2,11,20,25$, and 35).

Three patients suffered relatively minor illness from infection. Case 2 developed right-sided chest pain and pyrexia. Radiography showed a right upper mediastinal shadow. At thoracotomy a cyst filled with pus was removed. The cyst lining had been destroyed by inflammation. Case 11 was a baby aged 1 year who presented with an acute febrile illness and developed stridor. Radiography showed a right upper mediastinal shadow. At thoracotomy an acutely inflamed cyst was removed and the child recovered. Case 20 presented with chest pain and haemoptysis and a chest $x$-ray showed a middle lobe opacity with a fluid level. At thoracotomy an infected cyst lined by squamous epithelium was removed.

Case 25 had been known to have a right upper mediastinal shadow since the age of 6 years. Operation was advised in 1963 (Fig. 2a) but the patient declined because he was asymptomatic. In 1966 he was admitted to a medical unit because of acute chest pain. The pain was mainly in the right costal margin but radiated up the right side of the chest into the neck, jaw, and gums. The pain was of only moderate severity and the patient was ambulant in the ward. Radiography (Fig. 2b) showed that the mediastinal shadow had increased in size and two days later it was still larger. The patient agreed to surgery and arrangements were made for his transfer to the thoracic unit. However, before this could be arranged, he had a sudden attack of severe crushing retrosternal pain radiating into the neck. He was hypotensive and his jugular veins were grossly engorged. A chest film (Fig. 2c) showed that the mediastinal shadow had greatly increased in size, the cardiac shadow was enlarged, and there was a right pleural effusion. An emergency right thoracotomy was performed. At operation there was a $300 \mathrm{ml}$ right-sided pleural effusion. A large cystic upper mediastinal swelling had ruptured into the pericardium which contained a large quantity of turbid fluid. The heart action and the patient's general condition improved dramatically when the pericardium was opened and the tamponade relieved. The cyst which was attached to the trachea was excised. The patient made an uneventful recovery and was well five years later when he emigrated to Canada.

Case 35, a doctor, presented with loss of weight and cough, and had on one occasion vomited foul-smelling brown material. The chest film showed a posterior mediastinal opacity. At thoracotomy a large posterior mediastinal cyst was

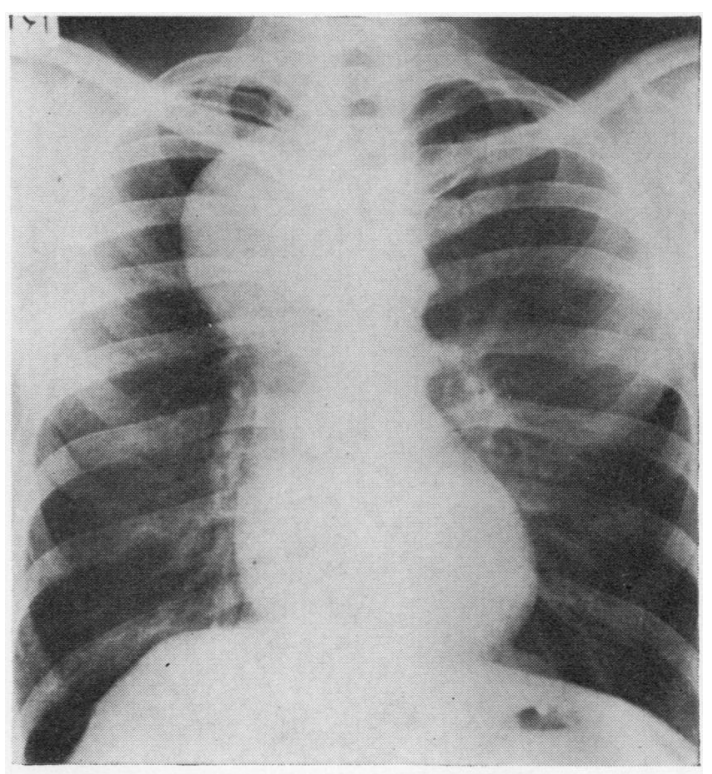

(a)

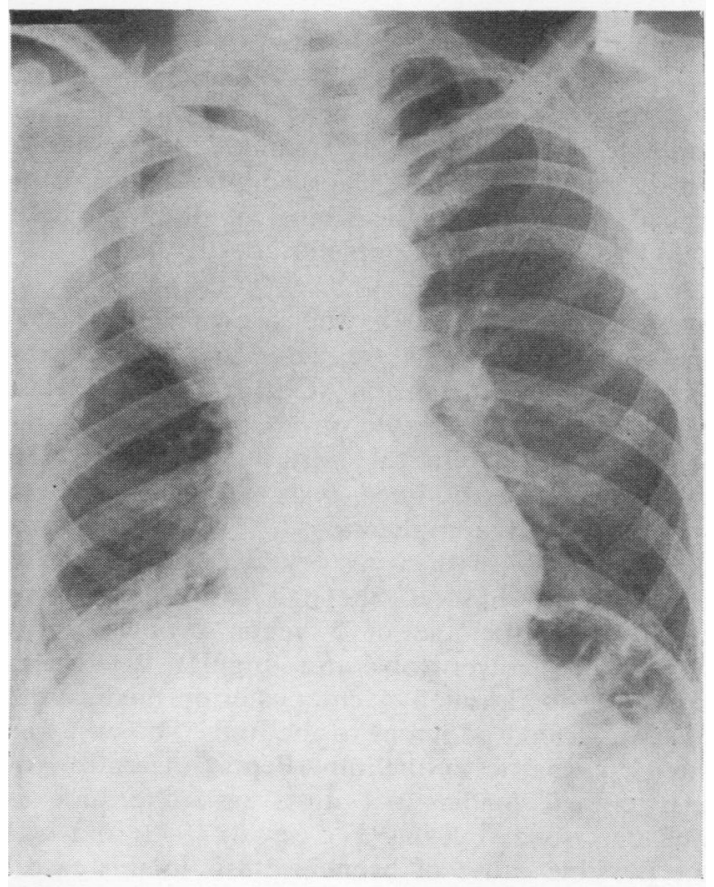

(b)

FIG. 2. See text 


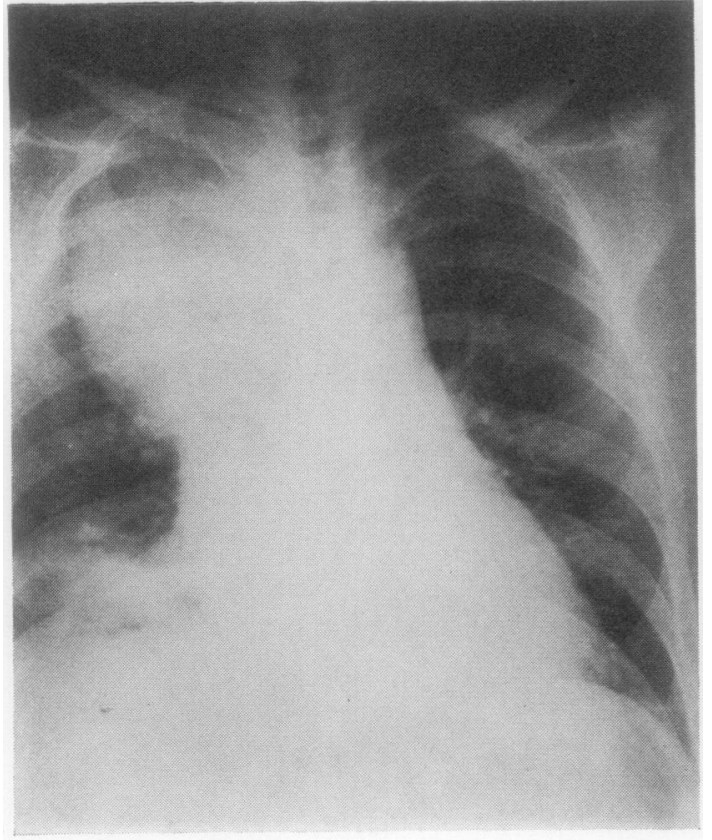

(c)

FIG. 2. See text.

found to have ruptured into the oesophagus. After removal of the cyst the oesophageal defect was repaired and the patient is now well. The contents of the cyst closely resembled the material which the patient had earlier vomited. On histological examination the lining of the cyst was found to have been completely destroyed.

PEPTIC ULCERATION It is well known that gastriclined mediastinal cysts are prone to complications due to peptic ulceration (Christoffersen, 1948 ; Nicholls, 1940 ; Matheson, Cruickshank, and Matheson, 1952). In this series two patients (30 and 41) had gastric-lined cysts, and one of these (41) developed complications. This patient was a girl aged 17 with a history of epigastric pain since early childhood. She had had a productive cough since the age of 5 years. Bronchograms showed left lower lobe and lingular bronchiectasis. At operation a $4 \mathrm{~cm}$ posterior mediastinal cyst was found adherent to the lung. The cyst was lined by gastric epithelium. Peptic ulceration of gastric-lined mediastinal cysts into the lung is well described (Böss, 1937 ; Seydl, 1938) and was the possible cause of bronchiectasis in this case.

TRACHEAL OBSTRUCTION In addition to case 11, already described, one other patient developed stridor. Case 15 had had, two years previously, a spinal radiograph for cervical spondylosis. At that time a right upper mediastinal shadow was noted. She developed increasing breathlessness and later stridor, and at bronchoscopy the lower trachea was seen to be narrowed to a slit. At operation a $5 \mathrm{~cm}$ cyst was removed from behind the lower trachea. Operation when the cyst was first noticed would have avoided this distressing and dangerous complication.

When a mediastinal shadow presents as a chance finding in an asymptomatic patient, reluctance to advise thoracotomy is understandable. However, this is an unacceptable attitude on two grounds-first, the difficulty (and sometimes impossibility) of making a firm diagnosis and, second, the fact that many of these mediastinal lesions tend to undergo complications which may be serious or lethal. This paper demonstrates the risk of complications ( 7 out of 41 cases) in cystic foregut derivatives and again emphasizes how serious these complications may be. Unless there is some important contraindication, it is the duty of a surgeon to recommend thoracotomy at the time that the mediastinal lesion is first recognized.

We wish to express our thanks to Mr. A. Logan and Mr. J. D. Wade for their kind permission to study their patients.

\section{REFERENCES}

Bentley, J. F. R., and Smith, J. R. (1960). Developmental posterior enteric remnants and spinal malformations. Arch. Dis. Childh., 35, 76.

Böss, C. (1937). Kongenitale, mit magenschleimhaut ausgekleidete im Mediastinalcyste mit in die Lunge penetrierendem chronischem Ulcus pepticum. Virchows Arch. Path. Anat., 300, 166.

Christoffersen, J. C. (1948). Intrathoracic gastric cyst. Acta chir. scand., 96, 12.

Fallon, M., Gordon, A. R. G., and Lendrum, A. C. (1954). Mediastinal cysts of foregut origin associated with vertebral abnormalities. Brit. J. Surg., 41, 520.

Laipply, T. C. (1945). Cysts and cystic tumors of the mediastinum. Arch. Path., 39, 153.

le Roux, B. T. (1962). Intrathoracic duplication of the foregut. Thorax, 17, 357

Maier, H. C. (1948). Bronchiogenic cysts of the mediastinum. Ann. Surg., 127, 476.

Matheson, A., Cruickshank, G., and Matheson, W. J. (1952). Gastric cysts of the mediastinum with a report of 2 cases. Arch. Dis. Childh., 27, 533.

Morrison, I. M. (1958). Tumours and cysts of the mediastinum. Thorax, 13, 294.

Nicholls, M. F. (1940). Intrathoracic cyst of intestinal structure. Brit. J. Surg., 28, 137.

Seydl, G. N. (1938). Eine kongenitale Magenwandcyste im Mediastinalraum mit in die Lunge perforiertem Ulcus pepticum. Frankfurt. Z. Path., 52, 346. 